\title{
GOVERNMENT POLICIES RELATING TO RESEARCH AND PATENTS
}

\author{
John A. Dienner*
}

This inquiry, concerning the policy to be pursued by the Government in respect to patent rights arising out of Federal research, necessitates an examination of the antecedents out of which the immediate question arises. Then we should examine the alternatives as to policy which are open to us to adopt, and the probable consequences of any policy recommended.

It appears to be the consensus of those concerned that the policy of the Government is not uniform and is not stabilized. The Attorney General has recommended, in his recent Report, ${ }^{1}$ that a stable policy, uniform throughout the various Government departments and agencies, be adopted.

The policy he recommends is, in effect, that wherever Government money has partly or wholly financed the activity in the course of which the invention is made, the invention should be assigned to the Government and patented by it, and the patent thrown open, free, to the people of the United States.

There have been large-scale expenditures of funds in war-stimulated development programs in the recent past. This has already produced startling changes in some parts of our economy, ${ }^{2}$ the full extent of which we do not realize. There are projected large-scale expenditures of funds through establishment of a National Science Foundation for research presumably on a peacetime basis. This also is likely to affect industry both widely and profoundly.

So now we are faced with the possibilities flowing from two related proposals, namely, that the Government will henceforth conduct scientific and industrial research and development on a vast scale, and the patents that will be granted on the inventions and discoveries thereby made will be taken over by the Government and thrown open, free, to the people of the United States. Does that mean that effective patents in the hands of private persons will be in only those remote corners and hedgerows of industry which the Government regards as wholly unimportant scientifically, industrially, or politically? It looks as if we are going to try to outrush the Russians.

But before we prostrate ourselves before this idol of the National Science Foun-

* Member of the firm of Brown, Jackson, Boettcher \& Dienner, Chicago, Ill.

${ }^{2}$ U. S. Dep't Justice, Report and Recommendations of the Attornex General to the President, Investigation of Government Patent Practices and Policies (r947), (hcreafter citcd as Rep. Atr'y GEN.)

${ }^{2}$ Report of the Patent Advisory Panez to the Atomic Energy Commission (September, 1947). See also First Report of the Atomic Energy Commission, Sen. Doc. No. 8, 8oth Cong., ist Sess. 4.5 (1947). 
dation rolling along on the Juggernaut of the Attorney General's recommended policy, let us challenge the validity of a few assumptions which this program demands for its acceptance.

The proposed program demands for its validity the acceptance of certain assumptions, among which are the following:

I. The assumption that the Government should on a peacetime basis expend vast sums in conducting indiscriminate research;

2. The assumption that it is sound policy for the Government to permit patenting of the inventions of its employees in any way connected with their employment;

3. The assumption that it is sound policy for the Government to demand of commercial contractors the same rights it at present demands of its own employees;

4. The assumption that private enterprise suppresses patents;

5. The assumption that the ownership of a patent by the Government is ipso facto beneficial to the people;

6. The assumption that the policy of private ownership of patents is less beneficial to the people than would be free dedication of inventions to the people;

7. The assumption that an invention which is not far enough (or is too far) ahead of present technology to be advantageously adopted will be any more likely to be adopted if the patent is thrown open to everybody;

8. The assumption that the necessity for secrecy is determinative of the rights of ownership of an invention.

\section{I}

I challenge the assumption that the Government should on a peacetime basis expend vast sums in conducting indiscriminate research.

Our friends, the scientists and politicians (what odd bedfellows!), now quote George Washington: "In times of peace prepare for war." Surely, they say, we can all join hands in a merry circle on that proposition. And, they say, in modern warfare all peacetime technology and materials, all facets of science, and all discoverable resources must be brought to bear upon developing ways to overcome the enemy. We must keep ahead of all other nations in scientific progress because in a "total war" you have to throw the whole arsenal at the other fellow's economy, and never mind sparing the women and children. They say that everything useful in peacetime economy becomes a necessity for waging war. Thus no distinction can be made between what we need in peacetime and what we need for war.

They say that if we do not overcome the other fellow (with atomic rocket bombs, radioactive dust, bacterial poisons, disease, or what have you) he will destroy us utterly with the same or even more deadly means. Instruments of destruction, they assure us, are now so terrific that no defense can withstand them. Hence the National Science Foundation is necessary to put us in possession of further terrible methods of destruction with supporting technology, so that if the other fellow even so much as makes a face at us, we can blow the living daylights out of him and his 
sisters and his cousins and his uncles and his aunts, even to the seventh generation.

They say that, in case of conflict, the nation with the superior science has the moral right to massacre the other nation to a man, leaving not so much as some old harmless fellow like G. B. Shaw with singed whiskers. That, they admit, is what is meant by the concept, "In times of peace prepare for war"-set to modern music.

But some pertinent observations may be made.

Scientists and politicians are not notable as moral leaders. Each group insists that it and it alone is the Moses to lead the National Science Foundation out of the wilderness. But since neither appears to be an adequate moral guide, might we not better let the Foundation stay lost for another forty years while the tribes regenerate their moralities?

Next, we may observe that the bellicose precept ascribed to Washington was never followed by the people of the United States. Never in our history have we entertained so absurd a proposition as the proponents of the Foundation now put before us, namely, to arm to the teeth in times of peace.

Further, we may observe that no nation has ever armed itself to the teeth without immediately going to war, or being immediately attacked. (Which way it was depends upon who is telling it.)

If the scientists and the politicians could catch the vision of inventing irresistible ways to establish peace and good will instead of irresistible ways of destroying humanity, the Foundation would have unanimous and universal support.

We know for a reasonable certainty that United States technology is plenteously good. Our industrial history proves it. No other country can surpass us, or even come close to being our equal, in the ability to turn the teachings of science into useful things, and to deliver them at a low price into the hands of the people. The opportunity for, and the remuneration resulting from, successful development and production of goods of all kinds has been greater in the United States than in any other country. We are a rich nation because we are productive of things useful to the people. War is wasteful and nonproductive of things useful to the people.

To do this great work of developing and producing new utilities, we have enlisted the intelligence of the people individually. We have always had enough science available because we have either pushed it ahead as we needed it, or we have bought or borrowed it wherever it was to be found. To us, a body of science which we could not shortly turn into something useful has had no particular appeal. We do not, as a people, worship science for its own sake, but look to it as being useful, first and foremost, and cultural incidentally. Can anyone point to a situation in which the United States has had to sit on its hands and wait for science to give it something to do? If so, it has not been publicized by those who could make the most of it. If we did not have the knowledge here, we borrowed some from the neighbors. Of course, no one speaks about what our neighbors may have borrowed from us in the meartime. Now we are to assume the job of discovering and inventing so fast and so furiously that nobody else will have a look-in. 
But the National Science Foundation is said to be intended to perform a new function, namely, to give us a plenteous supply of basic science, such as we are supposed to have borrowed from Europeans in times past. Now that Europe is so badly smashed up, we are told, we cannot look to the European scientists, but must do our own basic research and not only supply the threatened deficiency, but actually pre-empt all fields.

This has a peculiarly phony ring. We propose to scatter around half a billion or more dollars yearly to hire people to think and work out basically new scientific ideas and theories under Government control. If that is intended to reproduce the conditions under which the Europeans produced their best work, it would appear to be mistaken. The Europeans produced their contributions to science not because they were heavily subsidized, and organized and directed by other scientists or politicians, but because they worked as free individuals. ${ }^{3}$

If the Europeans, free of government control, could lead the world in basic science (as we are told) on boiled turnips, will a diet of caviar, spoon-fed by the Government, make the Americans see scientific visions and dream ultra-stellar dreams? Some of us doubt it. If the Europeans could produce pure science because they were without government control and subsidy, what will government control and subsidy do to our scientists?

Assuming that it is pure science that the Foundation is to generate, we might dismiss the consideration of patents, for in pure science patents are not involved. But the proponents of Government ownership of patents resulting from Government research get quite lyrical about the possibilities of patentable inventions. For example, the opening chorus in one recent opus begins, "A golden stream of patentable inventions pours from the scientific research and development conducted or financed by the Federal Government." scientist be satisfied to delve in pure science with this "golden stream" running between his fingers? He would quickly be pulled out of his orbit by the distracting forces inherent in that "golden stream." Competition for continued support by way of next year's appropriations would be difficult to maintain if a scientist merely discovers an unknown element in the spectrum of Saturn when all the other workers in the same vineyard are pouring out the "golden stream of patentable inventions."

Apparently the Foundation will find it necessary to be all things to all men, and yet to remain, like Caesar's wife, above reproach.

The scientists will strive for scientific freedom. They want freedom from the politicians. One of their spokesmen, John R. Baker, says: $:^{5}$

The great biochemist, Szent-Györgyi, has written these words: "What I want to stress is that the pre-condition of scientific discovery is a society which does not demand 'useful-

${ }^{3}$ John R: Baker, Science and the Planned State (1945).

'Kreeger, The Control of Patent Rights Resulting from Federal Research, XII LAW AND ConTEMP. Pros. 714 (1947).

BAKER, op. cit supta note 3 , at $42-43$. 
ness' from the scientist, but grants him the liberty which he needs for concentration and for the conscientious detailed work without which creation is impossible. . . The real scientist . . . is ready to bear privation and, if need be, starvation rather than let anyone dictate to him which direction his work must take." These are the opinions of the man who was the first to isolate a chemically pure vitamin. He is a Nobel Prizewinner for Medicine.

The politicians will be interested in the "golden stream" and will be likely to demand that some of it be diverted into the local irrigation ditches of their constituents.

If the Foundation is to devote itself to pure science, there will be difficulties in finding suitable personnel who will submit to political domination. Again I quote Baker: 6

... If the selection of scientific personnel is left to the state, the wrong men are likely to be given important posts, because those who are not themselves scientists will be led astray by the false claims and pretences of ignorant and foolish persons. As we have seen, such persons may even become academicians and be given wide powers to control scientific research. Worse still, scientists may exhibit a servile obedience to their political bosses and let dogmas and slogans affect their science.

In the United States we have a great deal of so-called industrial research carried on by industry. It is an appendage or adjunct of industry to the extent that it attempts to push related scientific knowledge ahead of the needs of that industry. It may be said that this is narrow and utilitarian, but so far we have done wonders with it. The question is now raised: Could the Government do it better?

If the Government's money is to do this class of work, the Foundation will be nothing more than another intrusion of Government into private industry. It will merely be an attempt of the Government to do what private industry can do and is doing very satisfactorily now. Might it not become the yardstick, constructed (like TVA) as a standard by which to measure rates, but also certainly well designed to be laid across the back of an enterprise that fails to go along?

An attempt to conduct research and development out of relation to civilian enterprise is not likely to be realistic or useful. Science and useful arts have many diverse possibilities. Who knows what all the problems are, and which ones should be solved now to meet the needs of industry and the people?

If we should all wait for a bureau at Washington to solve our problems for us, what would happen in the meantime? Suppose you are selling washing machines. Your competitor comes out with a new model and begins to sweep you off the market. What would you do? Appeal to Washington for a competing development? If so, you would probably, after a more or less protracted period of delay, receive the information that the Washing-Machine Division of the Foundation has been discontinued because some scientist in the Clothing Division of the Foundation has discovered that paper shirts can be made out of cornstalks. It has been found,

${ }^{6} I d$. at $75-76$. 
the communication would go on to say, that people who wear these shirts gladly throw them away after the first use, thereby establishing them as disposable. Hence, research for the washing machine industry has been discontinued as per a recent directive. The advice would then follow that you could obtain, on suitable application, a free license along with $140,000,000$ other citizens to go into the cornstalkpaper-shirt-business-and lose your shirt.

Competition is a personal sort of a thing. If you could write the ticket in Washington by which each competitor could meet his competition, you would merely be doing what everyone is now hustling around and doing for himself. But if you attempt to favor one over another, you are destroying the natural balance which results from individual initiative, and discouraging private enterprise. You cannot expect to help competitive enterprise by removing the means by which people compete.

Let us take the matter to its logical conclusion. Assume that the Foundation is so successful that it supplies all necessary inventions and discoveries free to everybody. Will that promote progress of science and useful arts? The constitutional policy of promoting the progress of science and useful arts by the patent system will then have been effectively nullified. Going through the motions of first patenting and then throwing open to the public is merely abracadabra having no significance-observing the form but destroying the substance. To the extent that the Foundation is successful in inventing, patenting, and throwing open to the public, it removes to that extent the intended functioning of the patent system.

If there were no patents on anything, everybody would have a free license without any nonsense. Is that what the scientists and politicians are striving for?

If the Government should begin to supply free apples to everybody who had an apple stand, everybody else would put up an apple stand, and shortly the appleselling business would be ruined. If this "golden stream of patentable inventions" flows freely into everybody's pocket, who will have a competitive advantage? But if it is made to flow only to some pockets and not to others, who will make the selection? Some people might be dissatisfied.

What is to be the measure of the projects to be undertaken and the amount of money to be spent? Here the proponents of the Foundation are a bit vague. Perhaps a combination of lucky numbers is as good in this case as it has been in other weighty governmental determinations, such as the price of gold in the devaluation of the dollar. Lucky numbers might be a little strange to the scientists, but they would have to get used to them.

As I have heretofore pointed out, there is a natural rate of assimilation of scientific progress in the industrial economy of this country which cannot be exceeded except at great cost, as in our war effort. You cannot, in a peacetime economy, bring out in one year six successive new models of the Ford automobile, but in wartime you can bring out as many successive new models of the Sherman tank as the 
war situation demands. Cost then is not the controlling factor. It would appear to be far more natural to push science and technology ahead of industry only about as fast as needed if peacetime conditions are to be considered, than for the Government to push science and technology ahead faster than industry can assimilate it. ${ }^{7}$ The Foundation is not a valid peacetime need. It is essentially a war measure, because it is not tied to peacetime needs, but is expected to arm us for war. The appropriations so far proposed for the Foundation have no relation to the industrial output to be effected. Industrial enterprises relate their appropriations for research programs to the volume of their business and the state of competition. No such controlling factors can operate on Government appropriations. Will the appropriations be made on a fear basis, or on a pork-barrel basis, or on a lucky-number basis?

Let us ask one more question on this subject. What is going to happen in respect of inventions or discoveries by the National Science Foundation that have a profound or even decisive military value, and have also highly valuable civilian possibilities? Will they be patented, assigned to the Government, and the patents thrown open to the public? I doubt it. Is not the National Science Foundation bound to hold them under secrecy just as the Atomic Energy Commission is now charged with retaining in secret everything pertaining to the production of fissionable material and its use in weapons? Unavoidably, things which would be of great interest for civilian purposes are kept under the wraps of secrecy because they have potential use in warfare. The difficulty with secrecy is that it is like a forest fire. Either you have got to put it out or it spreads. When you make one thing secret you must make the next thing to it secret, and so on indefinitely.

Assume that the National Science Foundation finds something approaching in importance the fission of the atom. Will it be thrown open to the public, or will it be kept secret? Since, as our scientist friends assure us, practically every discovery of science has some military value, who will be so bold as to release any information which some appropriate bureaucrat regards as having potential military value, no matter how great its peacetime value? The result will be that the National Science Foundation will begin to suffer from the constipation of secrecy. And if the Foundation should take on a wider and wider scope, might not our whole economy become affected with the same disorder?

It appears that we are not sufficiently emerged from a war psychology to consider objectively whether there is any justification for the National Science Foundation and its huge Government expenditures, presumably for peacetime purposes. Perhaps, in the present condition of world affairs, we must ask ourselves whether we regard war or peace as the normal condition. Perhaps for some time we must do our plowing with the sword ready to hand.

T Scientists assure us that basic scientific discoveries cannot be forced and the conditions under which they are made cannot be prescribed. They say a scientific discovery is the unpredictable reaction of chance suggestions in a fertile mind free of restraint. Some people think the scientists are not beyond putting on a show for their own benefit. But if you take them at their word, it rules out the fleshpots of the National Science Foundation. 
II

I challenge the assumption that it is sound policy for the Government to permit patenting of the inventions of its employees in any way connected with their employment.

Let us first sketch briefly the historical development of the law covering the relation of employer and employee.

The Federal Government has, since early times, been confronted with the legal question of what rights it has in inventions made by its employees. The Supreme Court and the inferior courts, in a series of controlling decisions, ${ }^{8}$ most of them before the turn of the century, defined the rights of the Government and its employee inventors as a development of the law of master and servant.

The Court said, in effect, that these rights depend upon the facts of the situation. There are two typical situations:

$x$. Where the invention is directly in line with and results from performance of an assigned employment, title and all rights go to the Government; ${ }^{9}$

2. Where the invention does not fall within the assigned employment (even though based on a subject closely allied with assigned duties), title remains in the inventor. ${ }^{10}$ The Government, where the facts warrant, may claim a shop right.

At about the same time there was a development in the law of contracts concerning the right of an employer to compel assignment by an employee under contract to assign inventions relating to the employer's business. The controlling decisions established that a contract to assign future inventions is not contrary to public policy, and that the employment itself is adequate consideration.11

So we come up to the present discussion with the background of settled law on three general propositions:

I. Without a contract to assign, the employee is obligated to assign those inventions to which the performance of his duties looked. In the absence of a contract, he is not obligated to assign any other inventions;

2. By contract any arrangement of rights in employees' future inventions may be provided for;

3. That the two foregoing propositions of law apply equally to the Government and its employee, and to the private employer and his employee. ${ }^{12}$

In the judicial determination of the rights of the Government and of the employee, there was no occasion to determine fundamental policy, because the function of the court is purely judicial, i.e., laying down the law, not enacting it.

${ }^{8}$ Solomons v. United States, 137 U. S. 342 (I890); McAleer v. United States, I50 U. S. 424 (I893); Gill v. United States, I6o U. S. 426 (I896); Standard Parts Co. v. Peck, 264 U. S. 52 (I924); United States v. Dubilier Condenser Corporation, 289 U. S. I78 (1933).

- Solomons v. United States, supra note 8.

${ }^{10}$ United States v. Dubilier Condenser Corporation, supra note 8.

${ }^{11}$ Continental Windmill Co. v. Empire Windmill Co., 6 Fed. Cas. 366 , No. 3,142 (C. C. N. D. N. Y. $187 \mathrm{r}$ ).

19 Standard Parts Co. v. Peck, supra note 8. 
It was decided that employment by the Government of a worker in the capacities set forth in the decided cases did not deprive the employee of the right to make inventions useful to the Government or to take patents on them, subject of course to the rights of the Government in or under the resulting patent. ${ }^{13}$ That is to say, employment of a man by the Government as such does not automatically deprive him of the right to make inventions or to apply for and receive the grant of patents on them. Whether that policy should be continued is now the subject of our inquiry.

The patent system is essentially an instrument of state policy. There is no natural right in a patent to anybody. True, the patent does cater to the natural instinct of the creator of an idea, that he has some special property in the idea. His natural right in his discovery or invention includes the right to keep the matter to himself. If he wants to use it in secret that is his business. But if someone else is allowed to learn about it, or invents the same idea, even though later, there is nothing the first inventor can do about it. That is about the extent of the natural right of the inventor.

But the center of gravity of the patent system has long since shifted its locus from the inventor, as such, to the one who produces the invention and supplies it to the public. The fruit of the patent system is a new device or a new utility or a new method in the hands of the people at a price which they can afford to pay.

The patent gives the producer a protected market in respect of the invention for a limited time, namely, the life of the patent. That protection of the market gives him some assurance on which he is justified in taking the risks which he must undertake in applying the technology of all the relevant arts to the production of the invention, the employment of capital and labor, and the creation of sales, all of which are involved in the venture. The modern manufacturing corporation in the United States hires its inventors, and maintains its staff of engineers to develop the idea and design a suitable embodiment of it. It maintains a production force with suitable machinery and operates a sales and service force to deliver the new device into the hands of the people at a price which they can pay and to help them keep it in such condition that it has its maximum utility.

In brief, in a modern competitive enterprise, invention, engineering, production, and sales are integrated in one unitary activity.

If there is any doubt as to the extensive employment of inventors by corporations, one may refer to an issue of the Official Gazette of the United States Patent Office, and compare the number of patents issued directly to assignees who are corporations with the total number of patents issued that week. The percentage runs between 50 per cent and 60 per cent. The percentage has been climbing and is climbing. One engaged in practice knows from experience that most of these assigned patents represent inventions made by employees of the assignee corporation.

It is important to examine more closely this phenomenon of inventors employed ${ }^{13}$ United States v. Dubilier Condenser Corporation, supra note 8. 
under contract to invent. The employment is voluntary. It is a truism that each man seeks that which he considers to be to his best advantage. Obviously, if a skilled inventor does not wish to be employed under contract to assign his inventions, he need not be so employed. There still are individuals who prefer to rely upon their own resources, make their own inventions, and sell or license them to manufacturers. But compared with the numbers and the skills of corporationemployed scientists and inventors, the number of lone-wolf inventors is insignificant. It is true that occasionally an inventor, not in the employ of anyone so far as producing inventions is concerned, brings in a new worth-while idea. While such inventions are rare, they are occasionally very valuable. The patent system cannot ignore them, but again we must remember that governmental policy must be administered for the general benefit, and not to serve exceptions.

Now for privately employed inventors under contract, the employment is adequate incentive to invent. This is the experience in industry generally. If an inventor employed by a corporation makes a notable contribution, it is the usual policy to increase his salary or to give him a bonus. The incentive of the patent is transferred to the corporation, and the corporation puts the invention, when it is successfully designed and engineered and produced, into the hands of the people.

The patent is conceived as an instrument of state policy, based largely upon human psychology. It offers the inducement of gain through the exploitation of an exclusive market for the invention. It has a powerful hold upon the human desire for gain which may be secured through the activity of supplying the new device to the people, which thus results in raising the standard of living.

In brief, the basic policy of the patent is founded on the assumption that the exclusive market which it insures is sufficient incentive to the owner to make a profit by producing and selling the invention in that protected market.

Now when a Government employee makes an invention, and is required to assign it to the Government, the incentive to invent which he has is certainly no greater than the incentive to invent which the similarly situated privately employed inventor has; in fact, it is generally less, because the Government finds it more difficult to increase out of his class the pay of the meritorious individual than does the private employer, and, since the Government does not market the invention, it has no measure of its value.

The Government does not have the ability or the facilities to put an invention on the market and get it into the hands of the people. The patent in Government hands therefore fails of its purpose. Throwing the patent open to all the people destroys the protected market which is the essence of the patent, and which is its specifically valuable feature in promoting the production of the invention and the placing of it in the hands of the people.

There is one feature of the use of a patent on which there is an almost complete lack of understanding, except by those who are engaged in industry. That feature 
is the highly specialized and expensive work required to design a device for manufacture and sale, and to design the special tools and manufacturing process to produce it. The point is simply this: that before any invention can be put upon the market, the form in which it is to be manufactured and sold and the process by which it is to be produced require a great amount of study and developmental work in order to embody in the article and in its method of manufacture all of the relevant technologies which bear upon its construction and use, as well as upon the methods of its production. This application of the appropriate technologies of all related industries is required in modern manufacture of any product. Any patented or unpatented product which enters a competitive market must be engineered and designed, even if it is so simple a thing as a screw-driver. The shank must be made of the right kind of steel. That can be determined only by experience or experimental tests. The technology of steel must be applied. The shank must be forged to shape, and that requires knowledge of metal-working and forging machines. It must be polished and ground to the right size and shape. The grinding and polishing require all the technology of the abrasive art and the polishing art. The selection of the handle, if it is to be made of plastics, involves the technology of the plastic art. If the handle is to be molded on the shank, then there is required the appropriate technology of plastic molding. Each material in and each operation on so simple a thing as a screw-driver calls for the specialized knowledge and technology of the specific art which has been separately developed to perform that step.

Much more difficult is the application of the appropriate technology to a new idea where there is nothing to go by.

Now it is competition which compels this application of the highest stage of modern technology to each manufactured article, for if $A$ sells his screw-driver, which does not embody all the modern technologies, $B$ will supply one and push $A$ out of the market. Even though the article is patented, the manufacturer must apply all technologies available, and continue to embody such improvements in all of the technologies as are available, first, to meet the competition of substitutes which lie outside the patent, and, second, in order to be sure that when the patent expires he will not be on the market with a horse-and-buggy article which will immediately be pushed out of the market by the competition of others who have applied modern technology to the production of the article on which the patent is no longer in force.

What this leads up to is that when the Government issues a free license to anybody to make a newly patented article, it is rare indeed that anyone will rush in and undertake the development and testing necessary to produce a commercial article containing all the applicable technologies, unless he has some advantage in the market which will keep others from immediately copying his work and underselling him on the market. 
No one can point to any important industry founded on a non-exclusive license. David Lloyd Kreeger, writing on The Control of Patent Rights Resulting from Federal Research, cites the Attorney General's Report in support of the statement that "the experience in the agencies which permit the employee to retain the patent rights is that he almost always sells it to a company operating in the field."14 In other words, the patent thus falls into the hands of him who can use it, and becomes useful in promoting the marketing of a new invention, if the invention has such merit. The assignment of a patent to the Government, with the issuance of free licenses to everybody, does not have the same result. The question then is, as a matter of policy, would it not be better policy to insure the patent's arriving in the hands of a producer who can use it, since it must ultimately land there to be of any benefit as a patent? How can that beneficial result be secured?

Now there is a class of employees in the Government, namely, the officers and employees of the Patent Office, who are prohibited by law ${ }^{15}$ from owning, except by inheritance or bequest, any right or interest in any patent issued by the Patent Office.

The incentive to invent certainly is not an element entering into the outlook of this employment. However, the examiners in the Patent Office are all technically trained men, some of them highly skilled engineers, and some of them scientists. ${ }^{10}$

It is here proposed that legislation similar to that applying to Patent Office examiners be made applicable to all Government employees, so far as concerns any subject which relates to their activities in pursuit of their employment.

It is well recognized that the arts are so far advanced that almost any invention which $A$ does not make today, $B$ will make tomorrow. A discovery which $X$ does not realize today, $Y$ will realize tomorrow. No one has ever complained about any inventions, which patent examiners might have made, being delayed until someone in private industry makes them. Likewise, no invention which other federal employees would be inhibited from making would be seriously delayed in its advent into industry because of such a prohibition. The benefit, however, would be that the invention, when it did arrive, through the mind of a non-government inventor, could, through the granting of the patent, have its proper effect in affording a protected market, and thereby it would offer the inducement to someone to initiate the business of supplying it to the public. If the patent system is sound, as the Constitution of the United States assumes, it should be given full freedom of operation.

This proposal to bar federal employees from taking any patents on inventions which might be made in the course of, or relating to the subject of, employment

\footnotetext{
${ }^{14}$ Kreeger, The Control of Patent Rights Resulting from Federal Research, XII LAW AND ConTEMP. Prob. 7I4, 733 n. III (I947), citing 2 REP. ATr'y GEN. 24, 5I, 55, I72-I73.

${ }^{25}$ Rev. StAT. $\$ 480$ (1875), 35 U. S. C. $\$ 4$ (1940).

${ }^{10}$ Note in this connection that Albert Einstein developed the most important part of his basic scientific theories while employed as an examiner in the Patent Office of Switzerland.
} 
paid for by federal funds is based on the same theory as the law respecting patent examiners, namely, that the denial of a right to a few is warranted by the benefit accruing to the many through the carrying out of a state policy. The patent system is an instrument of state policy and is to be so shaped as best to perform its intended function.

\section{III}

I challenge the assumption that it is sound policy for the Government to demand of commercial contractors the same rights it at present demands of its own employees.

A distinction needs to be made between federal employees, that is, individuals who are hired to give their personal services to the federal agency, and the contractor who undertakes to do a specific job of research or development, but who really is in the business of supplying goods or services to the people. While there undoubtedly are numerous cases of contractors who do specific jobs for the Government, and who may rely entirely on Government jobs, there is a vast difference between an individual federal employee who depends upon his salary as his business income and the contractor who is engaged in manufacture and sale of articles to the public, even though that public includes the Government.

The Government employee has no use whatsoever for the protected market which a patent gives him; and, as the Attorney General's Report suggests, such patents find their way into the the hands of companies who can use them. It would be of maximum benefit to everyone to allow the contractor, who has a business position in respect of the subject matter of the patent produced in the course of performance of his contract, to take title to the patent and give the Government its royalty-free license.

Contractors such as commercial laboratories or educational institutions which have no commercial business and cannot themselves use the protected market of the patent have no business messing into patentable inventions and discoveries, but should be confined to problems in science above the level of the patentable. They should be treated exactly as Government employees in respect of their contracts, and should be prohibited from taking patents, since it would be to the greater benefit of the people that they should not do so.

IV

I challenge the assumption that private enterprise suppresses patents.

The ownership of a patent, it is charged, gives the power of suppression of the invention. That, one might say, is a philosophical observation comparable to calling attention to the hole in a doughnut. But if and when the charge is made that the public is deprived, by suppression of a patent, of an invention for which there is any substantial unfilled demand in the market, it is time to inquire what is meant by suppression. Those who charge that patents are suppressed have been challenged to bring forth the evidence. What they have produced are instances in which 
inventions or improvements covered by patents have not been used. When inquiry is made as to why they were not used, or perhaps licensed to be used by others, there has in each case been found a reason based on the economics of the situation. If mere non-use by the owner of the patent, or any licensee, constitutes suppression, then the United States Government is the greatest suppressor of patents of all time. The Alien Property Custodian reports that he seized about 22,000 inventions on which there were patents or applications. He licensed about II,000, or half of them. Is the Government then suppressing about II,000 patents? The "golden stream" of these Ir,000 patents has ceased to flow.

The Alien Property Custodian has said that he will grant exclusive licenses. Thereby, he has asserted the power to exclude under the patent and has brought himself within the definition of suppression as it is used by those writers on patents who emphasize the hole in the doughnut.

I have pointed out that the inducement to gain by supplying the patented invention to the public in a protected market is the valuable feature of the patent. Gain, being the inducement, becomes the measure of the pull which the patent exerts for putting its invention on the market. If the economic conditions are such that no gain can be made, or the gain is not commensurate with the risk, obviously the owner of the patent will probably not use it. Anyone familiar with the development of the industrial arts and the principles of business management is aware that ideas must compete for entry into the market, and only the one which fits the requirements of the particular situation to the greatest advantage will be employed. The others will all probably die on the vine. In this respect they will be exactly like the Ir,000 unlicensed patents which the Alien Property Custodian holds.

$\mathrm{V}$

I challenge the assumption that the ownership of a patent by the Government is ipso facto beneficial to the people.

The essential and worth-while feature of a patent is the protected market for the new invention. The Government is in no position to utilize the protected market, and hence cannot use a patent for the purpose for which it is designed. If the Government holds the patent and the invention is not worked, then the Government is guilty of suppressing the patent. On the other hand, if free licenses are offered to everybody, the essential value of the patent is destroyed.

In the twenty-fifth chapter of Matthew there is reported the parable of the talents. A master going into a far country called his servants and delivered unto them his goods. To one he gave five talents, to another two, and to another one, bidding them trade with the talents until his return. Upon the master's return, the first servant reported a gain of five talents, the second servant a gain of two, but the third servant reported that he had hidden his talent in the earth. The master directed that he be relieved of the one talent and that it be given to the servant who had ten talents, commenting, 
For unto everyone that hath shall be given, and he shall havo abundance: but from him that hath not shall be taken away even that which he hath.

Now, putting a patent in the hands of the Government is like putting the talent in the hands of the third servant. About all the Government can do with a patent is to hide it in the earth. The patent in the hands of private industry tends to create wealth and initiates enterprise, but in the hands of the Government the patent is sterile and produces no gain. It should be taken from the inefficient servant and given to a real producer.

The theory on which our industrial system has been founded is that stated in the Constitution, namely, that the granting of patents, the effect of which is to grant a protected market in the new invention, promotes the progress of useful arts, that is, progress in our industrial system. While undoubtedly industries are founded on the manufacture and sale of unpatented devices, the inducement to found an industry on a new device, the market for which is protected by a patent, is undeniably greater. That is the testimony of all industrialists. But so far, no one has come forward with an example of the founding of an enterprise on a new invention where the enterprise had only a genuinely non-exclusive license.

The Alien Property Custodian had ample opportunity to establish new industries based on patented inventions, for he had seized about 22,000 patents and applications from the enemy. No instance of a new industry founded on a non-exclusive license from the Alien Property Custodian is reported. It is reported that some of those who took free licenses from the Alien Property Custodian and put them into use found, in preparing the inventions for the market, that they had to introduce improvements. ${ }^{17}$ These improvements, we may safely assume, were promptly

${ }^{17}$ Kreeger, supra note 14 , at 740 .

patented. If the free license was adequate, why the need for improvements? The broad proposition is this: The basic purpose of the patent is to put in the hands of a producer a protected market in the invention, in order to stimulate the producer to make money by putting the invention in the hands of the public. Delivering the patent into the hands of the Government is destruction of the system to that extent. So long as the extent of Government ownership is small, the effect on our economy may not be noticed. But if, as proposed, the Government is to enter the field of inventing and patenting on a large scale, the beneficial working of the patent system will to that extent be diminished, and may alter the character of our economy. Ownership by the Government of a patent on an invention destroys the effective value of the patent, and it is the patent which supplies the strongest inducement for getting the invention on the market.

\section{VI}

I challenge the assumption that the policy of private ownership of patents is less beneficial to the people than would be free dedication of inventions to the people.

To sustain this challenge, we need only look at the industrial history of the United States under its patent system. Should we, as a nation, abandon our system of 
granting patents which confer protected markets for bringing the invention to the people, in favor of a system under which everyone can copy everyone else's product and process? We need not rely upon our own experience or conjectures. We can refer this question to world history. Every nation of any substantial industrialization has found it desirable to install a system of patent grants for inventions. About I879 Holland abandoned the granting of patents. In that year occurred the debates in the English Parliament as to whether Great Britain should continue the system of granting patents for inventions. Parliament decided that even in spite of the example of Holland, and despite all of the alleged disadvantages, which were greatly magnified in debate, it would continue the system of private patents for inventions. Shortly thereafter Holland re-established a patent system and has retained it ever since.

In 1876 , at the Philadelphia Centennial Exhibition, representatives of the Swiss government saw so many wonderful American inventions that they went back to their country and convinced their government of the need for installing a system of private patents for inventions. That system has persisted to the present time.

The head of the Prussian government long resisted the introduction of a system of patents for inventions, and not until July, I, I877, was there a national system of granting patents for inventions in the German Empire.

The inescapable conclusion is that the system of granting patents for inventions is beneficial. It is better than the scheme of freedom for everyone to copy the invention of every other one. The proposal for a National Research Foundation, implemented by the Attorney General's recommendation, would have the Government create all the inventions.it could, and release them to the public. This would to that extent create a situation exactly as though there were no patents. The granting of patents to the Government and free licenses to everybody is a meaningless ritual. Why should we go through the mumbo-jumbo of patenting the invention and proclaiming a free license under it, when the identical objective would be accomplished by mere publication of the invention? Probably this would reveal too plainly the destruction of the American patent system which, intentionally or unintentionally, is the inevitable result.

If the National Science Foundation, with free licenses to everyone under its patents on inventions, becomes a significant factor in the advancement of science and technology, it will to that extent impair the operation of the patent system, and disturb our present industrial system.

If, on the other hand, what the Nation Science Foundation generates, and the Attorney General throws open to the public, is merely raw material for inventions or discoveries which may be patented to private owners, it will become one of the greatest political pork barrels ever perpetrated. 


\section{VII}

I challenge the assumption that an invention which is not far enough (or is too far) ahead of present technology to be advantageously adopted will be any more likely to be adopted if the patent thereon is thrown open to everybody.

It is assumed by the proponents of the National Science Foundation and the Attorney General's policy that an invention which is not economically justifiable in a given state of industry will be promptly adopted if the patent thereon is thrown open to everybody. Obviously, if it is not advisable for economic reasons to introduce an improvement into one's product, the presence or absence of patent protection is immaterial. No one will go ahead and put out a product on which he will lose money just because there is no patent on it, or because it is under a free license.

Similarly, if an invention is too far ahead of its time it will not go into use, whether it is patented or unpatented. I call attention to the mercury turbine, the initial work on which was done by the General Electric Company as early as Igro; patents were issued at that time. There were two chief difficulties in the way of its coming on the market. First, the metallurgy of steels and the art of welding had not sufficiently advanced to make ready construction feasible. Second, although the invention offered economies in coal consumption, the low price of fuel and other cost factors were such that it did not offer a great enough inducement in the existing economy to warrant its introduction. It was not until the recent war, with its demand for increased power production, coupled with great scarcity of materials, that it came into use, as an adjunct of existing stations to increase their capacity, about 1943. Whether there had been any patents or not, that invention could not have gone into use until technology and industry caught up with it. If every. body had been free to make it and use it when it was first proposed, it would not have changed the picture. The same thing is true generally. The tossing around of free licenses on patents will have absolutely no bearing upon their coming into use where the controlling factors which determine the use are economic.

\section{VIII}

I challenge the assumption that the necessity for secrecy is determinative of the rights of ownership of an invention.

The argument is put forth that since many inventions, the making of which the Government will in part or in whole finance, are important for waging war, the Government should take complete title to them, because it will be easier to keep them secret. The proposition is obviously basically false.

Because of a quirk in the law, ${ }^{18}$ the Commissioner of Patents cannot avoid, in peacetime, the issuance of a patent disclosing restricted information; but under another provision of the law ${ }^{19}$ any application which has become the property of the Government, and which is certified by the head of any department of the

${ }^{18} 40$ Stat. 394 (1917), as amended, 35 U. S. C. $\$ 42$ (1940).

${ }^{10}$ Rev. STAT. 4894 (1875), 35 U. S. C. $\$ 37$ (1940). 
Government as important to the armament or defense of the United States, will not be abandoned if response to a Patent Office action is made within three years. The subterfuge of assigning a patent to the Government, with the understanding that it will be reassigned just before issue, has been employed. This subterfuge, of course, requires the cooperation of the actual owner. The deadening effect of secrecy is well known. Secrecy is, however, no reason for genuine Government ownership. Under present conditions, it is obviously desirable to maintain certain inventions in secrecy; witness the Atomic Energy Act of 1946 . If there is a genuine need for secrecy on subjects outside of atomic energy, statutory provision should be made, and this should include provisions for delaying the issuance of relevant patents. However, the imposition of secrecy should be based upon factual need, and not upon ownership by the Government. If the maintenance of secrecy is of national concern, it should of course be imposed, but not for a minute longer than is necessary. Under present conditions, it is not the necessity of the situation which controls, but Government ownership and certification. After the application is once owned by the Government and certified as important to national defense the statute which permits the imposition of secrecy provides no machinery for its removal when the need has passed. The desirability of secrecy and the desirability of Government ownership in a specific case are independent questions and should be treated as such on their merits.

\section{Conclusions}

I. The proposed policy that the Government should take title to all inventions, into the making of which Government funds have entered, will not cure anything. Taken with the proposed expenditure of vast sums of money in research, as through a National Science Foundation, it would be highly destructive of our industrial system and of the patent system.

2. It is here recommended that Government employees be prohibited from patenting any inventions relating in any manner to the subject of their employment.

3. It is here recommended that research laboratories and university laboratories and their employees, under Government contract in a specific field, be prohibited from taking patents in that field in respect of inventions made in the course of or as a result of the contract.

4. It is here recommended that any contractor in the business of supplying the people or the Government with goods or industrial services take title to all patents made under the contract and grant the Government a non-exclusive license.

5. If failure to market a patented invention for economic reasons is suppression, the Government is equally guilty with private owners.

6. The experience of various nations indicates that the institution of private patents for inventions is a sound policy to stimulate industrial enterprise. Freeing inventions when first made from patents is the destruction of a universally recognized value. 
7. Going through the motions of taking out a patent by the Government and throwing it open to the public is a mere mumbo-jumbo, equivalent to denying patents altogether on those inventions. If an invention is to be thrown open to the public, that can be done more simply and in a way which will reveal what is actually being done.

8. In respect of an invention which it is not economical to market, a free license to everybody will not bring it any more quickly on the market.

9. Secrecy for an invention and the right to the invention are two different things which should not be, but are being, confused. 